\title{
Steam Treated Sawdust as Soilless Growing Media for Germination and Growth of Horticulture Plant ${ }^{1}$
}

\author{
Ji Young Jung ${ }^{2} \cdot \mathrm{Si}$ Young $\mathrm{Ha}^{2} \cdot$ Jae-Kyung Yang $\mathbb{D}^{2, \dagger}$
}

\begin{abstract}
The major substrates used in soilless growing media are peat moss and perlite, where peat moss is a limited and expensive natural resource. Determination of appropriate substrates based on technical and economic feasibility is the vital aspect of research and the key to success in any soilless production system. This research work was performed to evaluate different low-cost and sustainable alternative substrate as soilless growing media for horticulture plant. The objective of this study was to compare the effect of sawdust species and steam treatment, for physico-chemical properties and growth of horticultural plant. This study involves the physical and chemical characterization and growth test of four substrate (pine sawdust, oak sawdust, steamed pine sawdust and steamed oak sawdust) in order to evaluate their use as components of growing media. Steamed oak sawdust $\left(121^{\circ} \mathrm{C}, 30 \mathrm{~min}\right)$ showed adequate physical and chemical properties compared to peat moss for their use as growing media. The growing media were prepared using different mixture proportion to grow Brassica campestris L., Festuca arundinacea and Lespedeza cyrtobotrya Miq. The highest germination, stem length and leaf area of Brassica campestris L., Festuca arundinacea and Lespedeza cyrtobotrya were observed in 30 minute steamed oak sawdust mixture growing media. The steam treatment condition of sawdust used in the growing media significantly positive affected the germination, the stem length and the leaf area.
\end{abstract}

Keywords : soilless, steamed sawdust, growing media, peat substitutes, horticultural plant

\section{INTRODUCTION}

Soilless growing media are easier to handle and may provide a better growing environment compared to soil (Bilderback et al., 2005). Since the transition to soilless growing media, the basic components have been peat, coir, vermiculite, and perlite. Most of them are com- bined with various materials, such as a mixture of peat moss and pine bark, or a mixture of peat moss and pine bark with mineral materials like perlite or vermiculite (Bragg, 1990).

Substrates containing only organic components often lose macroporosity over time. Decomposition of organics creates an overabundance of small particles that hold excessive

1 Date Received October 10, 2017, Date Accepted November 14, 2017

2 Division of Environmental Forest Science and Institute of Agriculture \& Life Science, Gyeongsang National University, Jinju 52828, Republic of Korea

${ }^{\dagger}$ Corresponding author: Jae-Kyung Yang (e-Mail: jkyang@gnu.ac.kr, ORCID: 0000-0003-0423-6398) 
water and reduce air porosity. A mixture of organic and inorganic components, such as pumice or perlite, can help maintain the percentage of large pores later in the growing season (Bilderback and et al., 2005). The properties of different material used as growing media exhibit direct and indirect effects on plant growth and production. The selection of a particular material depends on its availability, cost and local experience of its use (Klute, 1986). Physical and chemical features of alternative growing media such as degree of dispersion, $\mathrm{pH}$, porosity, water holding capacity, must be considered for choosing the materials (Ezure and Wilson, 1983). To provide optimal characteristics, substrates are generally composed of a mixture of different materials in varying proportions.

In recent years, alternative substrate components have been investigated to decrease costs and utilize more renewable products. Currently, the use of other crop residues and by-product were increased. Alternative growing media were generally residual materials such as wood waste, expanded rice hull, recycled used-mushroom-media, sawdust, coco peat, distillery wastes, municipal solid waste, sewage sludge, rice hull, coconut coir (Forján et al., 2017; Park et al., 2014; Kim et al., 2014; Kim et al., 2010; Bustamante et al., 2008; Ostos et al., 2008; Salifu et al., 2006; Wrigth et al., 2006; Bugbee, 2002).

Partially composted pine bark is one of the most widely used substitutes for peat moss and has been used for decades as a growing media (Ryan et al., 2014). Pine bark is the primary component in container nursery substrates, com- prising $60 \%$ to $80 \%$ by volume of most substrate blends. In addition to these alternative aggregates, many researchers have reported the effectiveness of using fresh pine wood in greenhouse substrates as both a peat and perlite replacement (Fain et al., 2008). Researchers in Virginia have used a similar approach in exploring the possibility of wood fiber sawdust for production of containerized nursery crops (Jackson et al., 2008; Wright et al., 2008). To summarize all this research, use of pine wood materials, as opposed to bark only, provides a suitable environment for plant growth with respect to substrate physical and chemical properties.

Wood wastes, such as sawdust, are often composted with manure or supplemented with fertilizer to supply the needed nitrogen. Because of the inherent differences in chemical properties between different woods, however, the suitability of sawdust as an organic growing media component is extremely variable. Sawdust is widely used as a growth medium component in areas with wood processing industries, because of its low cost, high moisture retention, and high availability. Usually, it forms a constituent (normally less than 50\%) in mixtures rather than being used as a stand-alone growth medium. The nursery and greenhouse industries can bypass the forest products industry by harvesting whole trees using independent contractors, thus avoiding dependency on the economic volatility of the forest products industry (Marinou et al., 2013).

Sawdust has been the standard growing me- 
dia in the greenhouse because of its low cost and relatively high plant productivity. Many studies have been carried out composted pine sawdust for growing media (Singh and Verma, 2015; Altland and Krause, 2012; Jackson et al., 2008).

The objective of this study was to compare the effect of sawdust species and steam treatment, for physico-chemical properties and growth of horticultural plant. Also, an experiment was conducted to study the potential of steam treated sawdust as soilless growing media component in production of horticulture plant.

\section{MATERIALS and METHODS}

\subsection{Substrate preparation}

The substrate included pine sawdust, oak sawdust, steamed pine sawdust and steamed oak sawdust. The steam process was performed as follows. Five hundred grams of sawdust was put into autoclave. The autoclave was subsequently heated to $120^{\circ} \mathrm{C}$ for $10,20,30 \mathrm{~min}$. Steamed sawdust was then recovered by distilled water washing $\left(60^{\circ} \mathrm{C}, 3 \mathrm{~h}\right)$. The substrate was air-dried and hammer-milled to a particle size of $-20 \mathrm{mesh} /+80 \mathrm{mesh}$, and then stored in sealed plastic bags at $4{ }^{\circ} \mathrm{C}$ until used. Peat moss and perlite were used as control (commercial growing media).

\subsection{Physical and chemical properties of substrate}

The physical properties of the substrate; total porosity and water holding capacity; were measured by Verdonck and Gabriels (Verdonck and Gabriels, 1992) methods. Total porosity is normally calculated from measurements of bulk density.

Water holding capacity of the oven dried media was determined. Substrate was filled into a pre-weighted plastic pot $(50 \mathrm{~m} \ell)$ and the weight of both the pot and the media was recorded. Demineralised water was slowly added to the media (2-3 times) until excess water was seen flowing out of the pot. The pots were allowed to sit in the drained water for 2-3 $\mathrm{h}$ into an aluminium trough and the wet weight of the media and the pot was recorded after removing the drained water. Three replications were used in all measurements. Water holding capacity was calculated as:

$$
\begin{aligned}
& \text { Water holding } \\
& \text { capacity }(\%)
\end{aligned}=\frac{- \text { Wet weight }(\mathrm{g})}{\text { Dry weight }(\mathrm{g})} \times 100
$$

The carbohydrate content was determined according to alditol acetate method (Voiges et al., 2012). Sample was hydrolyzed using a two-stage procedure : 1) $12 \mathrm{M} \mathrm{H}_{2} \mathrm{SO}_{4}(200 \mu \ell)$ for $1 \mathrm{~h}$ at room temperature and 2) $1 \mathrm{M} \mathrm{H}_{2} \mathrm{SO}_{4}(1.8 \mathrm{~m} \ell$ distilled water added to tube) for $1 \mathrm{~h}$ at $121^{\circ} \mathrm{C}$. Acetylation was performed at room temperature (10 min) with 1-methylimidazole $(200 \mu \ell)$ and $1 \mathrm{~m} \ell$ of acetic anhydride and $5 \mathrm{~m} \ell$ of double distilled water added to quench the reaction. The carbohydrate content was calculated as the sum of the individual sugar (arabinose, xylose, man- 
Table 1. Growing media in experiment

\begin{tabular}{cc}
\hline Growing media & Composition \\
\hline \hline PM & $90 \%$ Peat moss $+10 \%$ perlite (commercial substrate) \\
PS & $30 \%$ Peat moss $+10 \%$ perlite $+60 \%$ pine sawdust \\
PSS10 & $30 \%$ Peat moss $+10 \%$ perlite $+60 \%$ steam treated pine sawdust $(10$ min $)$ \\
PSS20 & $30 \%$ Peat moss $+10 \%$ perlite $+60 \%$ steam treated pine sawdust $(20$ min $)$ \\
PSS30 & $30 \%$ Peat moss $+10 \%$ perlite $+60 \%$ steam treated pine sawdust $(30$ min $)$ \\
OS & $30 \%$ Peat moss $+10 \%$ perlite $+60 \%$ oak sawdust \\
OSS10 & $30 \%$ Peat moss $+10 \%$ perlite $+60 \%$ steam treated oak sawdust $(10$ min $)$ \\
OSS20 & $30 \%$ Peat moss $+10 \%$ perlite $+60 \%$ steam treated oak sawdust $(20 \mathrm{~min})$ \\
OSS30 & $30 \%$ Peat moss $+10 \%$ perlite $+60 \%$ steam treated oak sawdust $(30 \mathrm{~min})$ \\
\hline
\end{tabular}

* Steam treated: Steam treatment temperature is $120^{\circ} \mathrm{C}$.

nose, galactose and glucose).

The carbon $(\mathrm{C})$ and nitrogen $(\mathrm{N})$ content in substrate were determined by using $\mathrm{CN}$ analyzer (Micro coder JM 10, G-Science Laboratory, Japan).

The mineral elements $(\mathrm{K}, \mathrm{Ca}, \mathrm{Mg}, \mathrm{Na}, \mathrm{Zn}$, $\mathrm{Fe}, \mathrm{Mn}$ and $\mathrm{P}$ ) of substrate were measured using inductively coupled plasma atomic emission spectrometry (ICP-AES, OPTIMA 3300 DV) to quantify aqueous constituents following $\mathrm{mi}-$ crowave digestion with $\mathrm{HNO}_{3}-\mathrm{H}_{2} \mathrm{SO}_{4}-\mathrm{HClO}_{4}$ solution.

The $\mathrm{pH}$ was measured in water extracts using a Orion pH meter (model 710, Thermo Scientific, USA) (Jeong et al., 2008). The pH in water extracts was measured at a soil/water ratio of $1: 5(\mathrm{w}: \mathrm{v})$ after $1 \mathrm{~h}$ in suspension for water.

Phenolic compound content was assayed using the Folin-Ciocalteu reagent, following Singleton's method slightly modified (Holderbauma et al., 2014). Phenolic compound content of substrate (three replicates per treatment) was expressed as $\mathrm{mg}$ gallic acid equivalents $\mathrm{g}^{-1}$ distilled water through the calibration curve with gallic acid $\left(\mathrm{R}^{2}=0.9994\right)$.

\subsection{Growing media preparation}

Peat moss, perlite and steamed sawdust and mixture of these were used to create nine treatment which were $: 1$ ) peat moss : perlite $=90 \%$ : $10 \%(\mathrm{w} / \mathrm{w}), 2)$ peat moss : perlite : pine sawdust $=30 \%: 10 \%: 60 \%(\mathrm{w} / \mathrm{w}), 3)$ peat moss : perlite : steamed pine sawdust $(10 \mathrm{~min})=$ 30\% : 10\%: $60 \%(\mathrm{w} / \mathrm{w}), 4)$ peat moss : perlite : steamed pine sawdust $(20 \mathrm{~min})=30 \%: 10 \%$ : $60 \%(\mathrm{w} / \mathrm{w}), 5)$ peat moss : perlite : steamed pine sawdust $(30 \mathrm{~min})=30 \%: 10 \%: 60 \%$ $(\mathrm{w} / \mathrm{w}), 6)$ peat moss : perlite : oak sawdust $=$ 30\% : 10\%: 60\% (w/w), 7) peat moss : perlite : steamed oak sawdust $(10 \mathrm{~min})=30 \%: 10 \%$ : $60 \%(\mathrm{w} / \mathrm{w}), 8)$ peat moss : perlite : steamed oak sawdust $(20 \mathrm{~min})=30 \%: 10 \%: 60 \%$ $(w / w), 9)$ peat moss : perlite : steamed oak sawdust $(30 \mathrm{~min})=30 \%: 10 \%: 60 \%(\mathrm{w} / \mathrm{w})$. Ratios of each component in each substrate are 
shown in Table 1.

\subsection{Growth test}

The plant species used to evaluate the suitability of the horticultural media were Brassica campestris L. (A), Festuca arundinacea (B) and Lespedeza cyrtobotrya Miq. (C). Seeds were surface sterilized by immersion in $10 \%$ sodium hypochlorite solution for $10 \mathrm{~min}$, rinsed three times with deionized water, soaked in deionized water for $2 \mathrm{~h}$, and finally sown in the prepared growing media. Twenty seeds of Brassica campestris L., Festuca arundinacea and Lespedeza cyrtobotrya were placed in petri dishes (three dishes per substrate) containing 10 $\mathrm{g}$ of each growing media (Table 1). The seed was cultivated in the green house at $27^{\circ} \mathrm{C}$ for 7 days duration in $16 \mathrm{~h} \mathrm{light/8} \mathrm{h}$ dark and a $70 \%$ relative air humidity. Steam length $(\mathrm{cm})$ and leaf area $\left(\mathrm{cm}^{2}\right)$ was measured by digital vernier calipers (Byun et al., 2012). Seed germination, steam length and were recorded every day.

The percentage of seed germination was calculated as follows:

$\begin{gathered}\text { Seed } \\ \text { germination } \\ (\%)\end{gathered}=\frac{\begin{array}{c}\text { Number of seeds } \\ \text { germinated in substrate } \\ \text { extract }\end{array}}{\begin{array}{c}\text { Number of seeds } \\ \text { germinated in control }\end{array}} \times 100$

\subsection{Statistical analysis}

Obtained data were subjected to analysis of variance to determine the growing media effects. Statistical analysis had been carried out with SAS statistical software and according to analyzing from ANOVA test and comparing data mean to Duncan test. Duncan's multiple comparison range test was used to determine significant differences between the means.

\section{RESULTS and DISCUSSION}

\subsection{Effect of steam treatment condition on physical and chemical properties}

Sawdust and steamed sawdust, used in growing media, can differ in their physical properties and chemical properties. The physical properties (total porosity and water holding capacity) and chemical properties (carbohydrate content, $\mathrm{C} / \mathrm{N}$ ratio, mineral element, $\mathrm{pH}$ and phenolic compound content) of substrates were shown in Table 2 - Table 6.

The total porosity of sawdust and steamed sawdust was presented in Table 2. The total porosity differed significantly among substrate, with total porosity of pine sawdust ranging from 68.1 to $73.8 \%$, total porosity of oak sawdust ranging from 82.5 to $88.9 \%$. The total porosity of sawdust increased with increasing steam treatment time. Also, steamed oak sawdust (10 min, $20 \mathrm{~min}, 30 \mathrm{~min}$ ) showed an total porosity value similar to that suggested by Abad et al. (2001) for an ideal substrate (> $85 \%)$.

On the other hand, the water holding capacity decreased, in general, with increased steam treatment time (Table 3). The water holding ca- 
Table 2. Effect of steaming time and species of sawdust on total porosity

\begin{tabular}{ccc}
\hline Species of sawdust & Steaming time $(\mathrm{min})$ & Total porosity (\%) \\
\hline \hline Pine sawdust & 0 & $68.1 \pm 0.9 \mathrm{~b}^{*}$ \\
& 10 & $68.1 \pm 1.6 \mathrm{~b}$ \\
& 20 & $69.4 \pm 0.5 \mathrm{~b}$ \\
\hline Oak sawdust & 30 & $73.8 \pm 0.7 \mathrm{a}$ \\
\hline & 0 & $82.5 \pm 1.2 \mathrm{c}$ \\
& 10 & $85.2 \pm 1.0 \mathrm{~b}$ \\
& 20 & $86.0 \pm 1.0 \mathrm{~b}$ \\
\hline
\end{tabular}

* Mean separation within columns each species by Duncan's multiple range test at $p=0.05$

Table 3. Effect of steaming time and species of sawdust on water holding capacity

\begin{tabular}{|c|c|c|}
\hline Species of sawdust & Steaming time $(\min )$ & Water holding capacity $(\%)$ \\
\hline \multirow[t]{4}{*}{ Pine sawdust } & 0 & $32.2 \pm 0.9 \mathrm{~b}^{*}$ \\
\hline & 10 & $31.3 \pm 0.6 \mathrm{~b}$ \\
\hline & 20 & $31.0 \pm 1.3 \mathrm{~b}$ \\
\hline & 30 & $30.7 \pm 1.5 \mathrm{a}$ \\
\hline \multirow[t]{4}{*}{ Oak sawdust } & 0 & $47.1 \pm 0.8 \mathrm{c}$ \\
\hline & 10 & $47.8 \pm 1.0 \mathrm{~b}$ \\
\hline & 20 & $49.1 \pm 0.8 \mathrm{~b}$ \\
\hline & 30 & $49.2 \pm 0.8 \mathrm{a}$ \\
\hline
\end{tabular}

* Mean separation within columns each species by Duncan's multiple range test at $p=0.05$

pacity of pine sawdust (32.2\%) was lower than water holding capacity of oak sawdust $(47.1 \%)$. Also, pine sawdust and steamed pine sawdust used in this study fell inside the interval of values of the water holding capacity for an ideal substrate $(50 \sim 70 \%)$ (Abad et al., 2001). The pine sawdust, 10 minute steamed sawdust, 20 minute steamed sawdust and 30 minute steamed sawdust had the lowest value of water holding capacity, which will negatively influence on the nutrient holding capacity of growing media.

Physical properties of steamed oak sawdust generally were in ranges similar to what would be expected of sphagnum peat (Abad et al.,
2001). Steam treatment of wood results in several changes in the physical and chemical properties of wood. These include: (1) degradation of the hemicelluloses to produce simple sugars which may undergo reversion reactions to form highly branched polysaccharides, (2) degradation of both the hemicelluloses and part of the cellulose to form furan type compounds, (3) thermal softening of the cell wall matrix, mainly lignin, (4) degradation of the hemicelluloses to form volatile break down products, (5) crosslinking between carbohydrate polymers and/or between lignin and carbohydrate polymers, and/or (6) an increase in cellulose crystallinity 
Steam Treated Sawdust as Soilless Growing Media for Germination and Growth of Horticulture Plant

Table 4. Effect of steaming time and species of sawdust on carbohydrate content

\begin{tabular}{|c|c|c|c|c|c|c|c|}
\hline \multirow{2}{*}{$\begin{array}{l}\text { Species of } \\
\text { sawdust }\end{array}$} & \multirow{2}{*}{$\begin{array}{c}\text { Steaming } \\
\text { time }(\mathrm{min})\end{array}$} & \multicolumn{6}{|c|}{ (\%, dry weight) } \\
\hline & & Arabinose & Xylose & Mannose & Galactose & Glucose & Total carbohydrates* \\
\hline \multirow[t]{4}{*}{ Pine sawdust } & 0 & $0.5 \pm 0.2 \mathrm{a}^{* *}$ & $3.2 \pm 0.1 \mathrm{a}$ & $0.8 \pm 0.1 \mathrm{a}$ & $1.5 \pm 0.2 \mathrm{a}$ & $26.8 \pm 0.3 \mathrm{a}$ & $32.8 \mathrm{a}$ \\
\hline & 10 & trace & $2.3 \pm 0.2 b$ & $0.8 \pm 0.2 \mathrm{a}$ & $0.5 \pm 0.1 \mathrm{c}$ & $26.3 \pm 0.1 \mathrm{ab}$ & $29.9 \mathrm{~b}$ \\
\hline & 20 & trace & $2.3 \pm 0.3 \mathrm{~b}$ & $0.6 \pm 0.1 \mathrm{ab}$ & $0.8 \pm 0.2 \mathrm{~b}$ & $26.5 \pm 0.4 \mathrm{ab}$ & $30.2 \mathrm{~b}$ \\
\hline & 30 & trace & $2.3 \pm 0.4 \mathrm{~b}$ & $0.4 \pm 0.1 \mathrm{~b}$ & $0.4 \pm 0.1 \mathrm{c}$ & $26.2 \pm 0.1 \mathrm{~b}$ & $29.3 \mathrm{~b}$ \\
\hline \multirow[t]{4}{*}{ Oak sawdust } & 0 & $0.9 \pm 0.3 \mathrm{a}$ & $10.0 \pm 0.8 \mathrm{a}$ & $3.0 \pm 0.2 \mathrm{a}$ & $1.5 \pm 0.2 \mathrm{a}$ & $29.7 \pm 0.2 \mathrm{a}$ & $45.1 \mathrm{a}$ \\
\hline & 10 & $0.4 \pm 0.1 \mathrm{~b}$ & $9.1 \pm 0.4 \mathrm{a}$ & $2.4 \pm 0.3 \mathrm{~b}$ & $0.8 \pm 0.1 \mathrm{~b}$ & $28.9 \pm 0.2 b$ & $41.6 \mathrm{~b}$ \\
\hline & 20 & $0.3 \pm 0.1 \mathrm{~b}$ & $9.2 \pm 0.2 \mathrm{a}$ & $2.1 \pm 0.1 \mathrm{~b}$ & $0.7 \pm 0.1 \mathrm{bc}$ & $28.7 \pm 0.1 \mathrm{~b}$ & $41.0 \mathrm{~b}$ \\
\hline & 30 & $0.3 \pm 0.2 \mathrm{~b}$ & $9.2 \pm 0.4 \mathrm{a}$ & $2.0 \pm 0.3 \mathrm{~b}$ & $0.5 \pm 0.1 \mathrm{c}$ & $29.7 \pm 0.3 \mathrm{a}$ & $41.7 \mathrm{~b}$ \\
\hline
\end{tabular}

* Total carbohydrate : arabinose + xylose + mannose + galactose + glucose

** Mean separation within columns each species by Duncan's multiple range test at $p=0.05$

(Esteves and Pereira, 2009).

Changes in particle size distribution and cell wall porosity are other important effects of steam treatment. These changes are mainly observed as a result of the chemical reactions occurring with the cell wall constituents (Ramos, 2003). Additionally, the use of both high pressure during the treatment and rapid decompression afterwards would help to weaken cell wall structure, thereby increasing both porosity and surface area (Castro, 1994). The porosity of the lignocellulosic materials (cellulose-hemicellulose-lignin) increases with the removal of the crosslinks (Tarkow and Feist, 1969). Physical characteristics are improved based on these results.

As shown in Table 4, the total carbohydrate content of oak sawdust $(45.1 \%)$ was higher than pine sawdust $(32.8 \%)$. The total carbohydrate content differed significantly among substrate, with total carbohydrate content of pine sawdust ranging from 32.8 to $29.3 \%$, total carbohydrate content of oak sawdust ranging from
45.1 to $41.7 \%$. The total carbohydrate content of sawdust increased with increasing steam treatment time. Steam treatment has decreased total carbohydrate contents to $3 \sim 4 \%$. The proportion of sugars that are decreased after steam treatment was dependent on the type of arabinose, xylose, mannose and galactose. The arabinose was completely removed at 30 minute steamed pine sawdust. However, glucose was no difference between sawdust and steamed sawdust. Sawdust was high carbohydrate content (organic matter), according to the steam treatment was confirmed that the hemicellulose is decomposed (Arenas-Cárdenas et al., 2017). Hemicellulosic sugar (arabinose, xylose, mannose and galactose) are amorphous heteropolysaccharides, which are sensitive to steam treatment (Ramos, 2003). The carbon in easily decomposed compounds, such as hemicellulosic sugar and cellulose, are quickly used as an energy source by soil microorganisms, which also need nitrogen for growth and reproduction (Senesi and Loffredo, 1999). 
Table 5. Effect of steaming time and species of sawdust on $\mathrm{C} / \mathrm{N}$

\begin{tabular}{ccccc}
\hline Species of sawdust & Steaming time (min) & $\mathrm{C}(\%)$ & $\mathrm{N}(\%)$ & C/N ratio \\
\hline \hline Pine sawdust & 0 & $50.3 \pm 0.2 \mathrm{~b}$ & $0.1 \pm 0.0 \mathrm{~b}$ & $503 \mathrm{a}$ \\
& 10 & $50.0 \pm 0.3 \mathrm{~b}$ & $0.1 \pm 0.0 \mathrm{~b}$ & $500 \mathrm{a}$ \\
& 20 & $49.9 \pm 0.4 \mathrm{~b}$ & $0.1 \pm 0.0 \mathrm{~b}$ & $499 \mathrm{a}$ \\
& 30 & $51.8 \pm 0.2 \mathrm{a}$ & $0.2 \pm 0.0 \mathrm{a}$ & $259 \mathrm{~b}$ \\
\hline Oak sawdust & 0 & $48.6 \pm 0.1 \mathrm{ab}$ & $0.1 \pm 0.0 \mathrm{~b}$ & $486 \mathrm{a}$ \\
& 10 & $48.4 \pm 0.3 \mathrm{~b}$ & $0.1 \pm 0.0 \mathrm{~b}$ & $484 \mathrm{a}$ \\
& 20 & $48.5 \pm 0.4 \mathrm{~b}$ & $0.1 \pm 0.0 \mathrm{~b}$ & $485 \mathrm{a}$ \\
& 30 & $49.1 \pm 0.3 \mathrm{a}$ & $0.2 \pm 0.0 \mathrm{a}$ & $246 \mathrm{~b}$ \\
\hline
\end{tabular}

* Mean separation within columns each species by Duncan's multiple range test at $p=0.05$

Table 6. Effect of steaming time and species of sawdust on mineral elements

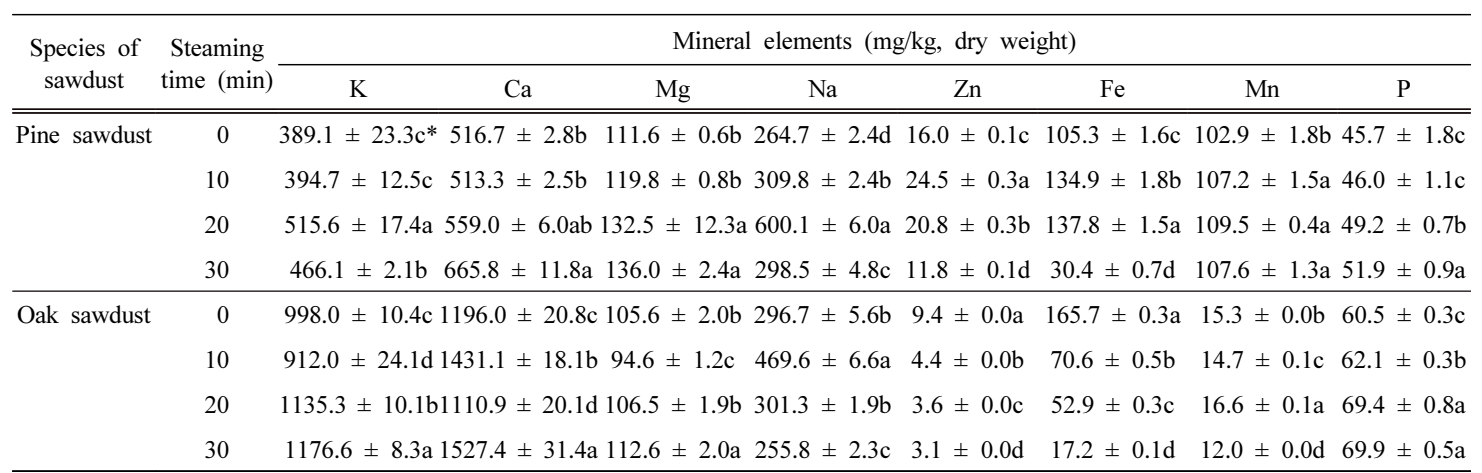

* Mean separation within columns each species by Duncan's multiple range test at $p=0.05$

In the steam treatment, significant decreases in $\mathrm{C} / \mathrm{N}$ ratio were observed (Table 5 ). The $\mathrm{C} / \mathrm{N}$ ratio differed significantly among substrate, with $\mathrm{C} / \mathrm{N}$ ratio of pine sawdust ranging from 503 to $259, \mathrm{C} / \mathrm{N}$ ratio of oak sawdust ranging from 486 to 246. During the steam treatment, the carbon $(\mathrm{C})$ and nitrogen $(\mathrm{N})$ increased, in the result, the $\mathrm{C} / \mathrm{N}$ ratio decreased. Also, the liberated compounds contain higher proportions of carbon $(\mathrm{C})$ than nitrogen $(\mathrm{N})$. The $\mathrm{C} / \mathrm{N}$ ratio of the sawdust and steamed sawdust exceeded the acceptable limit for an ideal substrate (50 70) (Abad et al., 2001). The $\mathrm{C} / \mathrm{N}$ ratio is a good indicator of whether nitrogen will be limiting or excessive; the higher the $\mathrm{C} / \mathrm{N}$ ratio, the higher the risk of nitrogen being unavailable to plants. However, this could be an advantage to avoid $\mathrm{N}$ immobilization due to high $\mathrm{C} / \mathrm{N}$ ratio (García et al., 1992). Wood wastes, such as sawdust, have very high $\mathrm{C} / \mathrm{N}$ ratio (400 to 1300) (Landis and Morgan, 2009). These materials are often composted with manure or supplemented with fertilizer to supply the needed nitrogen. The results of this study, it was confirmed that to reduce the $\mathrm{C} / \mathrm{N}$ ratio with the steam treatment. 
Mineral elements composition of sawdust and steamed sawdust were given in Table 6. Mineral elements showed not significant differences between sawdust and steamed sawdust with respect to potassium $(\mathrm{K})$, calcium $(\mathrm{Ca})$, magnesium $(\mathrm{Mg})$, sodium $(\mathrm{Na})$, zinc $(\mathrm{Zn})$, iron $(\mathrm{Fe})$, manganese $(\mathrm{Mn})$ and phosphorus $(\mathrm{P})$. Calcium $(\mathrm{Ca})$, together with potassium $(\mathrm{K})$, represented a significant part of the mineral element. The proportion of mineral element was $\mathrm{Ca}(513.3 \sim$ $1527.4 \mathrm{mg} / \mathrm{kg}$ dry wt), K $(389.1 \sim 1176.6 \mathrm{mg} / \mathrm{kg}$ dry wt $)>\mathrm{Na}(255.8 \sim 600.1 \mathrm{mg} / \mathrm{kg}$ dry wt $)>\mathrm{Fe}$ $(17.2 \sim 165.7 \mathrm{mg} / \mathrm{kg}$ dry wt), $\mathrm{Mg}(94.6 \sim 136.0$ $\mathrm{mg} / \mathrm{kg}$ dry wt $)>\operatorname{Mn}(12.0 \sim 109.5 \mathrm{mg} / \mathrm{kg}$ dry wt $>\mathrm{P}(45.7 \sim 69.9 \mathrm{mg} / \mathrm{kg}$ dry $\mathrm{wt})>\mathrm{Zn}(24.5 \sim$ $3.1 \mathrm{mg} / \mathrm{kg}$ dry wt). The available K (1176.6 $\mathrm{mg} / \mathrm{kg}$ dry wt), Ca (1527.4 mg/kg dry wt) and $\mathrm{P}(69.9 \mathrm{mg} / \mathrm{kg}$ dry wt) in 30 minute steamed oak sawdust were higher than for other substrates.

In general, the $\mathrm{pH}$ of oak sawdust increased with the increase of the time of steam treatment (Table 7). However, the $\mathrm{pH}$ of pine sawdust was almost the same. The $\mathrm{pH}$ differed significantly among pine sawdust and steamed oak sawdust, with $\mathrm{pH}$ of oak sawdust ranging from 4.4 to $5.5, \mathrm{pH}$ of pine sawdust ranging from 4.7 to 4.8. Except for 20 minute steamed oak sawdust ( $\mathrm{pH}$ 5.3) and 30 minute steamed oak sawdust ( $\mathrm{pH} 5.5)$, the $\mathrm{pH}$ of the substrates below the acceptable limit for an ideal substrate (Abad et al., 2001). According to Bunt (1988) the optimal $\mathrm{pH}$ range of media and mixes for growing ornamental plants in containers is 5.2 6.5. The results of this study, a $\mathrm{pH}$ of non-steam treated sawdust is slightly acid was, therefore, considered a limiting factor (Miller 2004).

The phenolic compound content of pine sawdust $(154.7 \mathrm{mg} / \mathrm{g}$ dry wt) was higher than that of oak sawdust (141.8 mg/g dry wt) (Table 7). Also, the phenolic compound content of sawdust decreased with increasing steam treatment time. The phenolic compound content of steamed pine sawdust (10 minute steamed pine sawdust $156.9 \mathrm{mg} / \mathrm{g}$ dry wt, 20 minute steamed pine sawdust $151.1 \mathrm{mg} / \mathrm{g}$ dry wt, 30 minute steamed pine sawdust $148.9 \mathrm{mg} / \mathrm{g}$ dry wt) was higher than steamed oak sawdust (10 minute steamed oak sawdust $141.1 \mathrm{mg} / \mathrm{g}$ dry wt, 20 minute steamed oak sawdust $134.7 \mathrm{mg} / \mathrm{g}$ dry wt, 30 minute steamed oak sawdust 126.4 $\mathrm{mg} / \mathrm{g}$ dry wt). The high phenolic compounds are expected to have a negative effect on growth. An indirect measurement method of phytotoxic compounds is phenolic compound measurement (Park et al., 2014). Additionally, Dorais et al. (2007) also indicate the possibility of phytotoxic effect of certain sawdust components upon the plant, such as phenols and terpenes. Losses also occurred through the escape of volatiles with the steam and through the degradation of sugars into furfural and 5-hydroxymethyl furfural, both of which are volatile compounds (Jeoh et al., 1998). In this study, the steam treatment was also confirmed that the phytotoxic (phenolic) compounds was reduced (Table 7). 
Table 7. Effect of steaming time and species of sawdust on $\mathrm{pH}$ and phenolic compound content

\begin{tabular}{cccc}
\hline Species of sawdust & Steaming time (min) & $\mathrm{pH}$ & $\begin{array}{c}\text { Phenolic compound content } \\
\text { (mg/g, dry weight) }\end{array}$ \\
\hline \hline Pine sawdust & 0 & $4.7 \pm 0.2 \mathrm{a}^{*}$ & $154.7 \pm 0.8 \mathrm{~b}$ \\
& 10 & $4.8 \pm 0.3 \mathrm{a}$ & $156.9 \pm 0.6 \mathrm{a}$ \\
& 20 & $4.8 \pm 0.4 \mathrm{a}$ & $151.1 \pm 0.3 \mathrm{c}$ \\
& 40 & $4.8 \pm 0.1 \mathrm{a}$ & $148.9 \pm 0.4 \mathrm{~d}$ \\
\hline Oak sawdust & 0 & $4.4 \pm 0.3 \mathrm{~b}$ & $141.8 \pm 0.3 \mathrm{a}$ \\
& 10 & $5.6 \pm 0.2 \mathrm{~b}$ & $141.1 \pm 0.4 \mathrm{~b}$ \\
& 20 & $5.5 \pm 0.3 \mathrm{a}$ & $134.7 \pm 0.0 \mathrm{c}$ \\
\hline
\end{tabular}

* Mean separation within columns each species by Duncan's multiple range test at $p=0.05$

\subsection{Effect of steam treatment condition on growth properties}

The growth properties (seed germination, stem length and leaf area) of PM (90\% peat moss and $10 \%$ perlite), PS (30\% peat moss, $10 \%$ perlite and $60 \%$ pine sawdust), PSS10 (30\% peat moss, $10 \%$ perlite and $60 \%$ steamed pine sawdust $(10 \mathrm{~min}))$, PSS20 $(30 \%$ peat moss, $10 \%$ perlite and $60 \%$ steamed pine sawdust (20 min)), PSS30 (30\% peat moss, 10\% perlite and $60 \%$ steamed pine sawdust (30 $\mathrm{min})$ ), OS (30\% peat moss, $10 \%$ perlite and $60 \%$ oak sawdust), OSS10 (30\% peat moss, $10 \%$ perlite and $60 \%$ steamed oak sawdust (10 min)), OSS20 (30\% peat moss, $10 \%$ perlite and $60 \%$ steamed oak sawdust (20 min)), OSS30 (30\% peat moss, $10 \%$ perlite and $60 \%$ steamed oak sawdust $(30 \mathrm{~min}))$ are presented in Fig. 1 Fig. 3.

Germination of Brassica campestris L. was found to be $44 \%, 49 \%, 53 \%, 55 \%, 51 \%, 57 \%$, $73 \%$ and $76 \%$ for the PS, PSS10, PSS $20, \operatorname{PSS} 30$, OS, OSS10, OSS20, OSS30, respectively.
Germination of Festuca arundinacea was found to be $34 \%, 61 \%, 77 \%, 76 \%, 45 \%, 49 \%, 80 \%$, and $79 \%$, respectively. Also, germination of Lespedeza cyrtobotrya was found to be $18 \%$, $27 \%, 38 \%, 38 \%, 21 \%, 39 \%, 43 \%$ and $45 \%$ for the PS, PSS10, PSS20, PSS30, OS, OSS10, OSS20, OSS30, respectively (Fig. 1).

In growing media consisting of a mixture of 30 minute of steam treatment time, the germination was similar to that observed in the PM (control). The germination of the Brassica campestris L., Festuca arundinacea and Lespedeza cyrtobotrya cultivated in the non-steam treated sawdust mixtures (pine sawdust, oak sawdust) were clearly lower than that of Brassica campestris L., Festuca arundinacea and Lespedeza cyrtobotrya cultivated with the steamed sawdust mixtures.

Stem length and leaf area were no difference between the substrate for Brassica campestris L. and Lespedeza cyrtobotrya (Fig. 2 and Fig. 3). However, the stem length and leaf area of the steamed sawdust mixture growing media were higher than that of the non-steam treated 

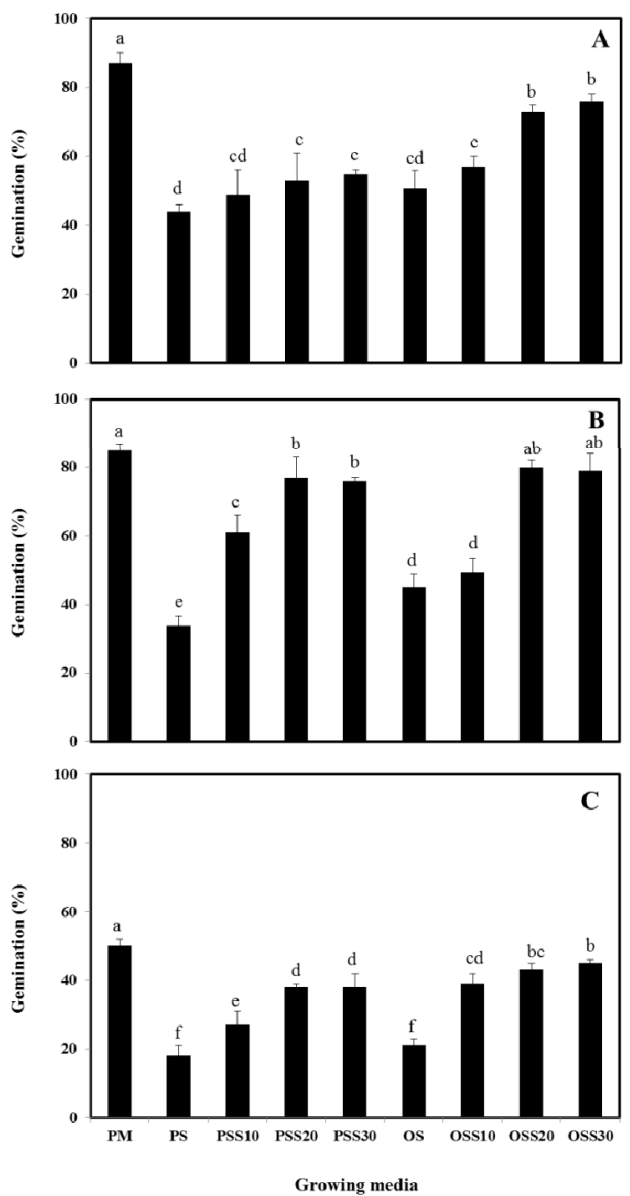

Fig. 1. Germination of Brassica campestris L. (A), Festuca arundinacea (B) and Lespedeza cyrtobotrya Miq. (C) grown in PM $(90 \%$ peat moss and $10 \%$ perlite), PS (30\% peat moss, $10 \%$ perlite and $60 \%$ pine sawdust), PSS10 (30\% peat moss, $10 \%$ perlite and $60 \%$ steamed pine sawdust (10 min)), PSS20 (30\% peat moss, $10 \%$ perlite and $60 \%$ steamed pine sawdust $(20 \mathrm{~min}))$, PSS30 (30\% peat moss, $10 \%$ perlite and $60 \%$ steamed pine sawdust $(30 \mathrm{~min})$ ), OS $(30 \%$ peat moss, $10 \%$ perlite and $60 \%$ oak sawdust), OSS10 (30\% peat moss, $10 \%$ perlite and $60 \%$ steamed oak sawdust $(10 \mathrm{~min}))$, OSS20 (30\% peat moss, $10 \%$ perlite and $60 \%$ steamed oak sawdust $(20 \mathrm{~min})$ ), OSS30 (30\% peat moss, $10 \%$ perlite and $60 \%$ steamed oak sawdust $(30 \mathrm{~min}))$. Vertical bars indicate standard error of the means. Duncan's multiple range tests at $p=0.05$.
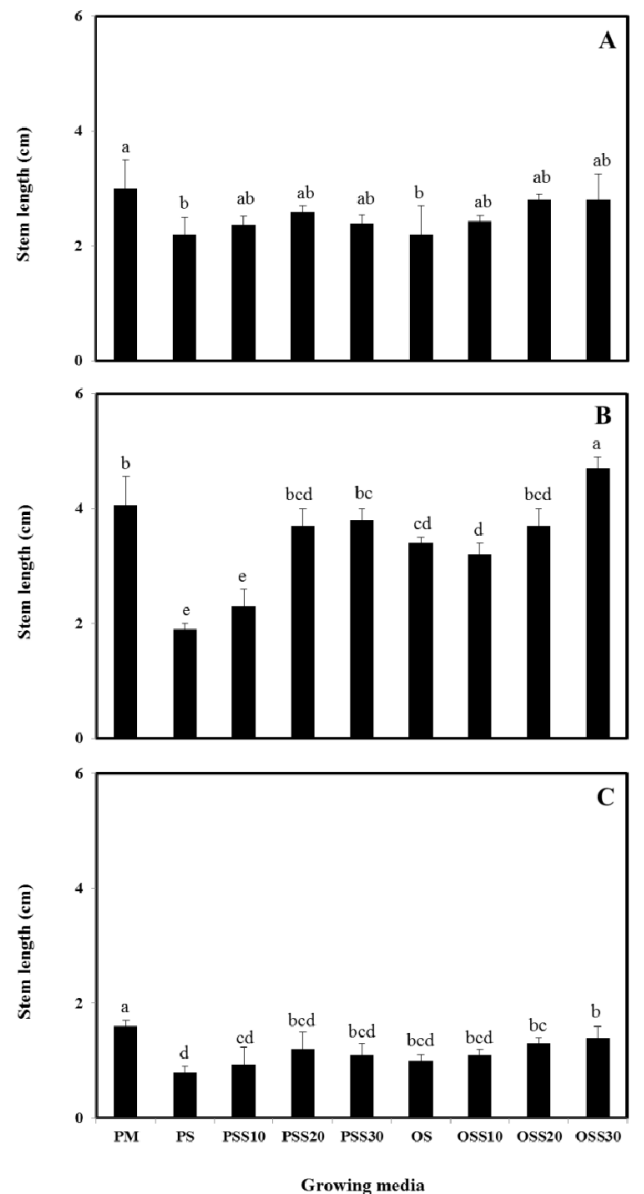

Fig. 2. Stem length of Brassica campestris L. (A), Festuca arundinacea (B) and Lespedeza cyrtobotrya Miq. (C) grown in PM $(90 \%$ peat moss and $10 \%$ perlite), PS (30\% peat moss, $10 \%$ perlite and $60 \%$ pine sawdust), PSS10 (30\% peat moss, $10 \%$ perlite and $60 \%$ steamed pine sawdust (10 min)), PSS20 $(30 \%$ peat moss, $10 \%$ perlite and $60 \%$ steamed pine sawdust $(20 \mathrm{~min}))$, PSS30 (30\% peat moss, $10 \%$ perlite and $60 \%$ steamed pine sawdust $(30 \mathrm{~min}))$, OS $(30 \%$ peat moss, $10 \%$ perlite and $60 \%$ oak sawdust), OSS10 (30\% peat moss, $10 \%$ perlite and $60 \%$ steamed oak sawdust $(10 \mathrm{~min}))$, OSS20 $(30 \%$ peat moss, $10 \%$ perlite and $60 \%$ steamed oak sawdust $(20 \mathrm{~min})$ ), OSS30 ( $30 \%$ peat moss, $10 \%$ perlite and $60 \%$ steamed oak sawdust $(30 \mathrm{~min})$ ). Vertical bars indicate standard error of the means. Duncan's multiple range tests at $p=0.05$. 

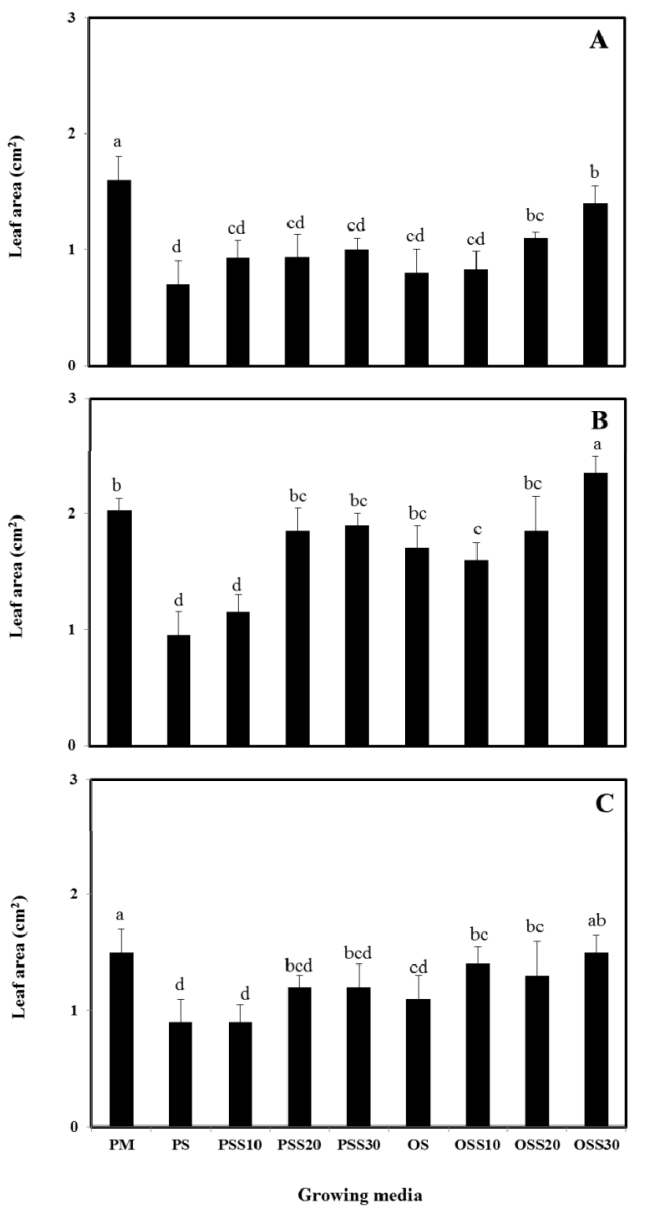

Fig. 3. Leaf area of Brassica campestris L. (A), Festuca arundinacea (B) and Lespedeza cyrtobotrya Miq. (C) grown in PM (90\% peat moss and 10\% perlite), PS (30\% peat moss, $10 \%$ perlite and $60 \%$ pine sawdust), PSS10 (30\% peat moss, $10 \%$ perlite and $60 \%$ steamed pine sawdust $(10 \mathrm{~min}))$, PSS20 (30\% peat moss, $10 \%$ perlite and $60 \%$ steamed pine sawdust $(20 \mathrm{~min})$ ), PSS30 (30\% peat moss, $10 \%$ perlite and $60 \%$ steamed pine sawdust (30 $\mathrm{min})$ ), OS $(30 \%$ peat moss, $10 \%$ perlite and $60 \%$ oak sawdust), OSS10 (30\% peat moss, $10 \%$ perlite and $60 \%$ steamed oak sawdust $(10 \mathrm{~min}))$, OSS20 (30\% peat moss, $10 \%$ perlite and $60 \%$ steamed oak sawdust $(20 \mathrm{~min})$ ), OSS30 (30\% peat moss, $10 \%$ perlite and $60 \%$ steamed oak sawdust $(30 \mathrm{~min})$ ). Vertical bars indicate standard error of the means. Duncan's multiple range tests at $p=0.05$. sawdust mixture growing media for Brassica campestris L. and Lespedeza cyrtobotrya. Also, the highest stem length and leaf area were observed in 30 minute steamed oak sawdust mixture growing media. The growth of the Festuca arundinacea cultivated in the steamed sawdust mixtures was clearly higher than that of Festuca arundinacea cultivated with the PM (control).

The steam treatment condition of sawdust used in the growing media significantly affected the germination, the stem length and the leaf area. The lowest growth (seed germination, stem length and the leaf area) in the pine sawdust could be due to the physical properties and the chemical properties, especially of phenolic compound content (Table 7).

The growth (seed germination, stem length and the leaf area) of Brassica campestris L., Festuca arundinacea and Lespedeza cyrtobotrya was confirmed to be improved (Fig. 1 Fig. 3).

\section{CONCLUSION}

An experiment was conducted to study the potential of steam treated sawdust as soilless growing media in plug seedlings production of horticulture plant (Brassica campestris L., Festuca arundinacea and Lespedeza cyrtobotrya Miq.).

This study involves the chemical, physical characterization and growth test of steam treated sawdust (pine and oak) in order to evaluate their use as components of horticultural media. Steamed sawdust showed adequate physical and 
chemical properties compared to peat moss for their use as growing media. Also, the steam treatment condition of sawdust used in the growing media significantly positive affected the germination, the stem length and the leaf area. Mixtures of varying proportions can be designed to take advantage of the positive characteristics of each substance and their interactions, in order to create optimal characteristics for plant growth (best water retention, $\mathrm{pH}$ levels, non-limiting salts, etc.) (Jung and Yang, 2014).

The chemical properties of sawdust can vary from species to another. In addition, the physical and chemical within a single plant vary with age, stage of growth, and other conditions. Sawdust of other tree species may also prove useful, but tests should be conducted before operational use.

This research indicates that steam treated sawdust may be utilized as a suitable replacement for peat moss in horticultural media component for horticulture plant.

\section{ACKNOWLEDGEMENTS}

This study was carried out with the support of 'R\&D Program for Forest Science Technology (Project No. 2013070D10-1719-AA03)' provided by Korea Forest Service(Korea Forestry Promotion Institute).

\section{REFERENCES}

Abad, M., Noguera, P., Bures, S. 2001. National inventory of organic wastes for use as growing media for ornamental potted plant production: case study in Spain. Bioresource Technology 77: $197 \sim 200$.

Altland, J.E., Krause, C.R. 2012. Substituting Pine Wood for Pine Bark Affects Physical Properties of Nursery Substrates. Horticultural Science 47(10): 1499 1503.

Arenas-Cárdenas, P., López-López, A., Eleonora Moeller-Chávez, G., León-Becerril, E. 2017. Current Pretreatments of Lignocellulosic Residues in the Production of Bioethanol. Waste and Biomass Valorization 8(1): 161 181.

Bilderback, T.E., Warren, S.L., Owen, J.S. Albano, J.P. 2005. Healthy substrates need physicals too! Hort Technology 15: 747 751.

Bragg, N.C. 1990. Peat and its alternatives. Hants, UK.

Bugbee, J.G. 2002. Growth of ornamental plants in container media amended with biosolids compost. Compost Science \& Utilization 10: 92 $\sim 98$.

Bunt, A.C. 1988. Media and mixes for container-grown plants (second ed.) Unwin Hyman Ltd., London, UK.

Bustamante, M.A., Paredes, C., Moral, R., Agullo, E., Perez-Murcia, M.D., Abad, M. 2008. Composts from distillery wastes as peat substitutes for transplant production. Resources, Conservation and Recycling 52: 792 799.

Byun, H.J., Kim, Y.S., Kang, H.M., Kim, I.S. 2012. Physicochemical characteristics of used plug media and its effect on growth response of tomato and cucumber seedlings. Journal of Bio-Environment Control 21: 207 212.

Castro, F.B. 1994. The use of steam treatment to upgrade lignocellulosic materials for animal feed. Ph.D. Thesis, University of Aberdeen, Scotland, UK, pp. $167 \sim 172$.

Costello, R.C., Sullivan, D.M. 2014. Determining the 
pH Buffering Capacity of Compost Via Titration with Dilute Sulfuric Acid. Waste and Biomass Valorization 5(3): 505 513.

Dorais, M., Menard, C., Begin, G. 2007. Risk of phytotoxicity of sawdust substrates for greenhouse vegetables. Acta Horticulturae 761: 589 $\sim 595$.

Esteves, B.M., Pereira, H.M. 2009. Heat treatment of wood. BioResource 4(1): 370 404.

Ezure, K., Wilson, V.J. 1983. Dynamics of neck-to-forelimb reflexes in the decerebrate cat. Journal of Neurophysiology 50: 688 695 .

Fain, G.B., Gilliam, C.H., Sibley, J.L., Boyer, C.R. 2008. Whole tree substrate and fertilizer rate in production of greenhouse-grown petunia (Petunia hybrida Vilm) and marigold (Tagetes patula L.). HortScience 43: 700 705.

Forján, R., Rodríguez-Vila, A., Pedrol, N., Covelo, E.F. 2017. Application of Compost and Biochar with Brassica juncea L. to Reduce Phytoavailable Concentrations in a Settling Pond Mine Soil. Waste and Biomass Valorization 1: 14.

García C., Hernández, T., Costa, F., Ayuso, M. 1992. Evaluation of the maturity of municipal waste compost using simple chemical parameters. Communications in Soil Science and Plant Analysis 23: $1501 \sim 1512$.

Holderbauma, D.F., Konb, T., Guerra, M.P. 2014. Dynamics of total phenolic content in different apple tissues and genotypes: impacts and relevance for breeding programs. Scientia Horticulturae 168: 58〜63.

Jackson, B.E., Wright, R.D., Barnes, M.C. 2008. Pine Tree Substrate, Nitrogen Rate, Particle Size, and Peat Amendment Affect Poinsettia Growth and Substrate Physical Properties. Horticultural Science 43(7): 2155 2161.

Jeoh, T. 1998. Steam explosion pretreatment of cotton gin waste for fuel ethanol production.
Master's thesis, Virginia Tech. University, VA. Jeong, S.J., Oh, J.S., Seok, W.Y., Cho, M.Y. 2008. The effect of treatment of woody charred materials on the growth and components of tomato and Chinese cabbage. Korean Journal of Organic Agriculure 16: 455 469.

Jung, J.Y., Yang, J.K. 2014. The suitability evaluation of lignocellulosic substrate as growing media substitute. African Journal of Biotechnology 13(14): $1541 \sim 1549$.

Kim, C.H., Oh, T.S., Shin, D.G., Cho, Y.K., Kim, Y.W., Ann, S.W. 2014. Study on the development of horticultural media using recycled used-mushroom-media. Journal of Environmental Science International 23: $303 \sim 312$.

Kim, H.L., Kim, H.D., Kim, J.G., Kwack, Y.B., Choi, Y.H. 2010. Effect of organic substrates mixture ratio on 2-year-old high bush blueberry growth and soil chemical properties. Korean Journal of Soil Science and Fertilizer 43: 858 $\sim 863$.

Klute, A. 1986. Methods of Soil Analysis Part 1. Physical and Mineralogical Methods. ASA/SSSAJ, Madison, WI.

Landis, T.D., Morgan, N. 2009. Growing media alternatives for forest and native plant nurseries. R.K. Dumroese, L.E. Riley (Eds.), National proceedings, forest and conservation nursery associations-2008, USDA For Serv, Rocky Mt Res Stat, Ft Collins, CO, USA (2009), pp. 26 31 Proceedings RMRS-P-58.

Marinou1, E., Chrysargyris, A., Tzortzakis, N. 2013. Use of sawdust, coco soil and pumice in ydroponically grown strawberry. Plant, Soil and Environment 10: 452 459.

Miller, M. 2004. Using compost successfully in propagation systems. International Plant Propagators' Society Combined Proceedings 53: $412 \sim 415$. 
Ostos, J.C., Lopez-Garrido, R., Murillo, J.M., Lopez, R. 2008. Substitution of peat for municipal solid waste and sewage sludge based composts in nursery growing media: effects on growth and nutrition of the native shrub Pistacia lentiscus L. Bioresource Technology 99: 1793 1800 .

Park, E.Y., Choi, J.M., Shim, C.Y. 2014. Development of root media containing carbonized and expanded rice hull for container cultivation of horticultural crops. Journal of The Korean Society for Horticultural Science 32: $157 \sim 164$.

Ramos, L.P. 2003. The chemistry involved in the steam treatment of lignocellulosic materials. Quim. Nova. 26 (6): 863 871.

Salifu, K.F., Nicodemus, M.A., Douglas, F.J., Davis, A.S. 2006. Evaluating chemical indices of growing media for nursery production of Quercus rubra seedlings. Horticultural Science 41(5): $1342 \sim 1346$.

Senesi, N., Loffredo, E. 1999. The chemistry of soil organic matter. In:Spark, D.L.(Ed), Soil physical chemistry. CRC press, Boca Raton, FL, pp. 239 $\sim 370$.

Singh, A., Verma, P.P.S. 2015. Survival and growth performance of stevia cutting under different growing media. Journal of Medicinal Plants Research 3(2): 111 113.

Tarkow, H., Feist, W.C. 1969. In: A Mechanism for Improving the Digestibility of Lignocellulosic Materials with Dilute Alkali and Liquid $\mathrm{NH}_{3}$ Advance Chemistry Series 95. American Chemical Society, Washington, DC, 197 218 .

Verdonck, O., Gabriels, R. 1992. Reference method for the determination of physical and chemical properties of plant substrates. Acta Horticulturae 302: $169 \sim 179$.

Voiges, K., Adden, R., Rinken, M., Mischnick, P. 2012. Critical reinvestigation of the alditol acetate method for analysis of substituent distribution in methyl cellulose. Cellulose 19: 993 $\sim 1004$.

Wrigth, R.D., Browder, J.F., Jackson, B.J. 2006. Ground pine chips as a substrate for container-grown woody nursery crops. The Journal of Environmental Horticulture 24(4): 181 184 .

Wright, R.D., Jackson, B.E., Browder, J.F., Latimer, J.G. 2008. Growth of chrysanthemum in ground pine trees requires additional fertilizer. Hort. Technology 18: 111 115. 